\title{
PENGASUHAN (GOOD PARENTING) BAGI ANAK DENGAN DISABILITAS
}

\author{
Oleh: \\ Gabriela Chrisnita Vani, Santoso Tri Raharjo, \& Eva Nuriyah Hidayat \\ Email: \\ Gabrielacv_68@yahoo.com; santosotriraharjo@gmail.com; enuriyah@yahoo.com; \\ sahadihumaedi@yahoo.com
}

\begin{abstract}
ABSTRAK
Setiap anak tidak terkecuali anak dengan disabilitas mempunyai hak untuk tumbuh dan berkembang, mendapatkan pendidikan, dan hak-hak lainnya. Akan tetapi jumlah anak disabilitas di Indonesia yang ternyata tidak sedikit harus diperhatikan bersama terutama oleh lingkungan terdekat atau orangtua. Hal ini dibuktikan dengan adanya jumlah anak penyandang disabilitas yang semakin meningkat dari tahun ke tahun menurut Pendataan Direktorat Rehabilitasi Sosial Penyandang Cacat Kementerian Sosial (2009), terdapat 65.727 anak, yang terdiri dari 78.412 anak dengan kedisabilitasan ringan, 74.603 anak dengan kedisabilitasan sedang dan 46.148 anak dengan kedisabilitasan berat. Lalu berdasarkan Susenas Triwulan 1 Maret 2011, jumlah anak Indonesia sebanyak 82.980.000. Dari populasi tersebut, 9.957.600 anak adalah anak berkebutuhan khusus dalam kategori penyandang disabilitas. Anak dengan disabilitas memerlukan penanganan khusus, tetapi tidak semua orangtua yang tulus menerima anak dengan disabilitas dan memberikan kasih sayang secara penuh hal ini dapat terlihat dari penerimaan orangtua yang sedih, malu, dan terkejut. Dengan penerimaan tersebut, akan mengakibatkan orangtua tidak memperdulikan anak dengan disabilitas dan kurangnya perhatian atau kasih sayang orangtua kepada anak dengan disabilitas. Belum banyak orangtua yang menerima anak dengan disabilitas dengan hati yang tulus, yang mengakibatkan kurang terpenuhinya hak dan kebutuhan anak dengan disabilitas. Dalam hal ini, perlu adanya pengasuhan baik dari keluarga terutama kedua orangtua anak. Pengasuhan yang baik akan menghasilkan anak dengan disabilitas dapat memenuhi kebutuhan dan mendapatkan hak mereka sehingga dapat berfungsi secara sosial. Perlunya edukasi akan fungsi keluarga yang memang harus dipenuhi yaitu afeksi, keamanan, identitas, afiliasi, sosialisasi, kontrol harus diberikan orangtua kepada anak penyandang disabilitas. Pelayanan sosial bagi keluarga juga dapat diterapkan diadakan misalnya dengan pelayanan konseling keluarga, family life education (pendidikan kehidupan keluarga), dan parent support group dapat dilakukan oleh pekerja sosial dalam memberdayakan orangtua serta anak dengan disabilitas. Kata kunci: orangtua anak disabilitas, pengasuhan, pelayanan sosial keluarga.
\end{abstract}

\section{PENDAHULUAN}

Anak-anak penyandang disabilitas adalah mereka yang sering kali tidak mendapatkan perawatan kesehatan atau bersekolah. Mereka yang paling rentan mengalami kekerasan, pelecehan, eksploitasi dan penelantaran, terutama jika mereka tersembunyi atau ditempatkan dalam lembaga seperti banyak dari mereka karena stigma sosial atau biaya ekonomi untuk membesarkannya. Menurut data Sussenas tahun 2003, di Indonesia terdapat 679.048 anak usia sekolah berkebutuhan khusus atau 21,42 \% dari seluruh jumlah anak berkebutuhan khusus. Sedangkan menurut sussenas 
pada tahun 2009, persentase jumlah anak penyandang disabilitas semakin meningkat yaitu Tuna Netra $10,71 \%$, Tuna Rungu 5,15 \%. Tuna Wicara 6,09 \%, Tuna Rungu Wicara 13,73\%, Tuna Daksa 31,71 $\%$, Tuna Grahita 22,07 \%, Tuna Ganda 8,25 \%, dan Gangguan Jiwa 2,29 \%. Anak dengan disabilitas mempunyai berbagai macam jenis hambatan. Setiap hambatan pada anak disabilitas mempunyai penanganan yang berbeda. Dalam data di atas jenis hambatan yang paling tinggi yaitu tuna daksa atau anak yang memiliki hambatan pada bagian tubuh.

Jumlah anak dengan disabilitas menurut RISKESDAS 2007, sekitar 4 persen dari anak usia 15 sampai 19 tahun mengalami kesulitan yang signifikan pada setidaknya satu domain fungsional (penglihatan, pendengaran, berjalan, berkonsentrasi dan memahami orang lain serta perawatan diri) dan oleh karena itu dianggap sebagai hidup dengan disabilitas. Sensus 2010 menemukan bahwa sekitar 2 persen dari anak usia 0 sampai 14 tahun memiliki disabilitas. Dua persen dari semua anak usia 0 sampai 18 di Indonesia berjumlah sekitar 1,5 juta anak, empat persen dari jumlah semua anak akan meningkatkan jumlah total sekitar 3 juta anak-anak dan remaja yang hidup dengan disabilitas.

Jumlah anak penyandang disabilitas semakin meningkat dari tahun ke tahun. Berdasarkan data Dinas Sosial Dinas Sosial jumlah penyandang cacat pada tahun 2011 adalah 29.110, yang terdiri dari 15.667 pria dan 13.443 wanita, sedangkan untuk tahun 2010 jumlah penyandang cacat adalah 36.607 , yang terdiri dari 19.867 pria dan 16.990 wanita.

Di 24 propinsi menurut Pendataan Direktorat Rehabilitasi Sosial Penyandang Cacat Kementerian Sosial (2009), terdapat 65.727 anak, yang terdiri dari 78.412 anak dengan kedisabilitasan ringan, 74.603 anak dengan kedisabilitasan sedang dan 46.148 anak dengan kedisabilitasan berat. Lalu berdasarkan Susenas Triwulan 1 Maret 2011, jumlah anak Indonesia sebanyak 82.980.000. Dari populasi tersebut, 9.957.600 anak adalah anak berkebutuhan khusus dalam kategori penyandang disabilitas. Sedangkan jumlah anak dengan kecerdasan istimewa dan berbakat istimewa adalah sebesar 2,2\% dari populasi anak usia sekolah (4-18 tahun) atau sekitar 1.185.560 anak.

Akan tetapi jumlah anak disabilitas di Indonesia yang ternyata tidak sedikit, harus diperhatikan bersama terutama oleh lingkungan terdekat atau orangtua. Karena anak dengan disabilitas memerlukan penanganan khusus, tetapi tidak semua orangtua yang tulus menerima anak dengan disabilitas dan memberikan kasih sayang. Orangtua terkadang tidak memperdulikan atau kurangnya perhatian atau kasih sayang orangtua kepada anak dengan disabilitas. Belum banyak orangtua yang menerima anak dengan disabilitas dengan hati yang tulus. Anak dengan disabilitas tidak merasakan diterima secara penuh di lingkungan keluarga terutama orangtua. Orangtua menganggap anak dengan disabilitas merupakan "aib" bagi keluarga. Begitu juga dengan stigma negatif bahwa anak dengan disabilitas hanya dapat menunggu bantuan saja dan tidak bisa melakukan aktivitas sendiri. Reaksi orangtua mempunyai anak dengan disabilitas juga bermacam-macam.

Berbagai emosi dan reaksi orang tua dengan kehadiran anak yang cacat, menurut model Cunningham (Cunningham's model of psychic crisis) menurut Yayasan Pendidikan Anak Cacat (YPAC) Tahun 2014, mengalami beberapa tahapan, yaitu:

1. Fase terkejut (shock phase)

Pada tahap ini timbul perasaan tragedy, orang tua panik, sedih karena melahirkan anak cacat. Reaksi anggota keluarga lain makin menambah perasaan ini, pada umumnya orang tua merasa mereka "lain" dari orang tua lainnya, merasa terkucil. Pada tahap ini timbul perasaan bingung, mengingkari, irasional, bahkan perasaan jadi tumpul. Pada tahap ini sikap ketakutan pada orangtua sangata muncul karena mereka merasa tidak sanggup mengurus anak dengan disabilitas. Orangtua tidak percaya mengasuh anak dengan hambatan yang dimiliki, namun hal tersebut sebenarnya salah, setiap anak adalah anugerah Tuhan yang memang harus kita jaga dan kita berikan kasih sayang.

\section{Fase bereaksi (reaction phase)}


Pada tahap ini orang tua mudah mengekspresikan perasaan duka yang dalam, kecewa, cemas, agresi dan perasaan gagal. Perasaan-perasaan ini menyebabkan orang tua takut berbuat kesalahan "lagi", mereka biasanya mencari bantuan dan pakar medis atau "ahli lain" sebagai satu-satunya dewa penolong dan menjadi sangat tergantung pada mereka. Pada tahap ini orangtua merasakan kecemasan dan gagal dalam mengasuh anak, maka itu orangtua lebih banyak melibatkan atau secara tidak langsung memberikan pengasuhan anak mereka kepada orang lain. Perasaan ini salah, karena seharusnya orangtua harus lebih banyak meluangkan waktu mengasuh anak mereka.

Dalam kenyataannya orangtua-lah yang selalu ada bersama anak sehingga merekalah yang paling kenal dengan perkembangan anaknya. Timbul kecenderungan bersikap terlalu melindungi anak dari kesulitan atau bahaya lain, terkesan bersikap memanjakan anak. Orang Tua spesial untuk "Anak Spesial". Reaksi lain adalah kontrol yang berlebihan (anak dilarang untuk melakukan berbagai kegiatan), sehingga mengurangi kesempatan untuk mendapatkan pengalaman sosial yang bervariasi. Dalam hal ini, orangtua mempunyai pengasuhan tidak melihat kebutuhan anak terlebih dahulu. Ada 2 jenis pengasuhan yang tidak baik, yang pertama orangtua yang selalu memanjakan anaknya dan yang kedua pengasuhan yang terlalu possessive yaitu anak tidak boleh melakukan hal-hal yang anak sukai karena semua yang dilakukan oleh anak dibatasi oleh orangtua.

\section{Fase penyesuaian (adaptation phase)}

Pada tahap ini orang tua secara realistik mulai menerima kondisi anak. Dalam tahap ini para ahli perlu memberikan banyak informasi mengenai keadaan anak, khususnya mengenali kemampuan kekuatan yang ada pada anak cacat dan upaya pengembangannya. Tahap ini, orangtua mulai berani menerima anak, mencari dan mengembangkan potensi yang ada dalam diri anak, mencari informasi terkait dengan pengasuhan anak dengan disabilitas.

\section{Fase orientasi (orientation phase)}

Orang tua mulai mengorganisasi pikiran dan perasaannya sendiri, berupaya mencari bantuan yang terarah \& sistematis dan melaksanakan program yang disarankan serta membuat rencana masa depan bagi anak cacatnya. Tahap ini, orangtua mulai berusaha mencari dan memfasilitasi perkembangan anak misalnya dalam pendidikan anak mulai dimasukkan ke SLB (sekolah luar biasa). Orangtua juga mulai mendengar saran misalnya dari lingkungan terdekat orangtua terkait dengan pengasuhan yang baik kepada anak dengan disabilitas.

Begitu juga yang diungkapkan oleh Duncan dan Moses (dalam Gargiulo, 1985) bahwa orangtua yang mempunyai anak dengan disabilitas akan mengalami 3 fase, yaitu:

1. Fase primary (Shock, denial, grief, depression)

2. Fase secondary (ambivalensi, guilt, anger, shame, embarrassment)

3. Fase tertiary (bargaining, adaption dan reorganitation, acceptance, adjustment)

\section{PEMBAHASAN}

Keluarga merupakan lingkungan yang paling dekat dengan anak, keluarga terutama orangtua bertugas untuk memberikan perlindungan serta kasih sayang kepada anak. Keluarga mempunyai pengaruh yang besar dalam pengasuhan kepada anak dengan disabilitas dengan tujuan anak dengan disabilitas dapat memenuhi kebutuhan mereka secara mandiri. orangtua wajib mendampingi anak, mengasuh anak, dan memberikan hak-hak yang seharusnya mereka miliki. Banyak keluarga khususnya para orangtua yang memandang "rendah" dan hanya bisa bergantung pada orang lain. ABK juga sama seperti kita mempunyai hak untuk mendapatkan pengahargaan. Menurut Menurut Heward (2003) menyatakan bahwa efektivitas berbagai program penanganan dan peningkatan kemampuan hidup anak berkebutuhan khusus akan sangat ditentukan oleh peran serta dan dukungan penuh dari keluarga, sebab keluarga adalah pihak yang mengenal dan memahami berbagai aspek dalam diri seseorang dengan jauh lebih baik daripada orang-orang yang lain. Di samping itu, dukungan dan penerimaan dari orangtua dan anggota keluarga yang lain akan memberikan 'energi' 
dan kepercayaan dalam diri anak berkebutuhan khusus untuk lebih berusaha mempelajari dan mencoba hal-hal baru yang terkait dengan ketrampilan hidupnya dan pada akhirnya dapat berprestasi. Orangtua pasti lebih mengenal anaknya dibandingkan orang lain, maka dari itu pengasuhan dari orangtua lah yang berpengaruh pada tumbuh kembang anak dengan disabilitas. Orangtua yang mempunyai anak dengan hambatan, merasa bahwa anak tersebut tidak berguna dan menimbulkan malu bagi keluarga. Padahal, seperti kita ketahui bahwa orangtua mempunyai peran penting dalam memberikan asuhan kepada anak. Jika pola pikir orangtua tertanam bahwa anak dengan disabilitas tidak dapat berdaya, hal ini akan mempengaruhi pengasuhan yang diberikan orangtua kepada anak. pengasuhan dapat diimplementasikan dengan fungsi pokok keluarga. Adapun fungsi pokok keluarga menurut Allender (1998):

1. Affection (Afeksi)

Fungsi affection yang dilakukan keluarga diantaranya adalah dengan menciptakan suasana persaudaraan/menjaga perasaan, mengembangkan kehidupan seksual dan kebutuhan seksual, serta menambah anggota keluarga baru. Orangtua dapat memberikan cinta kasih yang tulus dan rasa kasih sayang kepada anak.

\section{Security and Acceptance (Keamanan dan Penerimaan)}

Di dalam keluarga, fungsi keamanan dan penerimaan juga dibutuhkan. secara umum usaha yang dapat dilakukan yaitu dengan mempertahankan kebutuhan fisik, dan menerima individu sebagai anggota keluarga. Orangtua dapat menerima anak secara utuh dengan tidak mengatakan bahwa anak sebuah "aib" bagi keluarga serta memberikan rasa aman kepada anak.

\section{Identity and satisfaction (Identitas dan memuaskan)}

Keluarga merupakan suatu media yang dipergunakan untuk mengembangkan diri, yaitu mengembangkan peran dan self image, mempertahankan motivasi, dan mengidentifikasi tingkat sosial dan kepuasan aktivitas. Orangtua dapat membantu anak dalam mengembangkan dirinya, misalnya mencari dan memfasilitasi minat dan bakat anak.

\section{Affiliation and companionship (Afiliasi dan pertemanan)}

Fungsi ini dilakukan dengan mengembangkan pola komunikasi dan mempertahankan hubungan yang harmonis. Orangtua berusaha untuk membangun komunikasi yang baik dengan anak dan menjaga hubungan yang baik antar anggota keluarga.

\section{Socialization (Sosialisasi)}

Sosialisasi juga salah satu fungsi yang dilakukan dalam keluarga yang tujuannya untuk mengenal kultur (nilai dan perilaku) serta sebagai peraturan/pedoman hubungan internal dan eksternal. Pada akhirnya, sosialisasi juga bertujuan untuk melepas anggota keluarga. Misalnya saat anak sudah dewasa dan menikah. Orangtua dapat memberikan bimbingan sosial kepada anak misalnya mengenalkan anak kepada tetangga, teman, masyarakat.

\section{Controls (Kontrol)}

Keluarga juga berfungsi sebagai kontrol, yaitu mempertahankan kontrol sosial yang ada di keluarga. Selain itu fungsi kontrol dapat diterapkan untuk melakukan penempatan dan pembagian kerja anggota keluarga sesuai dengan peran mereka masing-masing yang pelaksanaannya dengan menggunakan sumber daya yang ada. Orangtua dapat memberikan kontrol kepada anak berupa monitoring secara intenif kepada anak.

Penerimaan orangtua kepada anak dengan disabilitas menjadi nilai tersendiri, pasalnya belum banyak orangtua yang dapat menerima anak dengan disabilitas secara penuh. Hal ini juga dapat menyebabkan kegelisahan tersendiri pada orangtua dan akibatnya menyebabkan parenting stress. 
parenting stress yaitu ketegangan yang berlebihan secara khusus terkait dengan peran orangtua dan interaksi orangtua dengan anak. biasanya parenting stress akan lebih tinggi pada pengasuhan anak. Seharusnya orangtua dapat menjadi role model bagi anak dan mencoba mengajarkan anak untuk mencoba melakukan pekerjaan rumah (kerumahtanggan), memberikan kasih sayang dan perhatian yang lebih kepada anak, tidak menganggap bahwa mengurus ABK sangat sulit karena hambatan yang dimiliikinya, membawa anak ke lingkungan luar, mengawasi anak. akan tetapi para orangtua sudah terlebih dulu khawatir dengan anak mereka. Akan tetapi dampak parenting stress ini, harus diatasi secara bersama-sama. Orangtua anak dengan disabilitas juga harus mendapatkan dukungan dari keluarga besar dan lingkungan di sekitar orangtua anak misalnya tetangga terdekat ataupun temanteman dari orangtua. Support dari keluarga besar ataupun lingkungan luar kepada orangtua menjadi kekuatan tersendiri agar orangtua dapat benar-benar yakin dan percaya diri untuk memberikan pengasuhan kepada anak dengan disabilitas, begitu juga dengan dukungan sosial yang diberikan kepada anak dengan disabilitas. Dukungan sosial yang diberikan kepada anak dengan disabilitas antara lain: Dukungan emosional, informasi, atau materi alat bantu yang diberikan. Dukungan sosial berpengaruh terhadap anak berkebutuhan khusus dalam membuat anak tersebut tidak merasa berbeda dari anak normal. Support, motivasi, semangat serta penghargaan bagi mereka sangat mempengaruhi psikis anak. dampaknya anak semakin yakin akan potensi yang ada dalam dirinya. Tak jarang orangtua tidak dapat melakukan coping strategy, dampaknya biaya perawatan untuk ABK pun tergolong mahal. Namun setidaknya terdapat tiga strategi yang biasa diadopsi oleh masyarakat di negara-negara maju dan berkembang seperti Australia (Ros \& Cuskelly, 2006), China (Chen \& Silbereisen, 2010), dan Iran (Assadi, 2011). Dalam hal pengasuhan, orangtua harus mengetahui bagaimana kondisi dan kebutuhan masing-masing anak. Pengasuhan yang baik kepada anak dengan disabilitas yaitu cara berkomunikasi. Jerome bruner (1975) menyatakan dengan kemampuan berkomunikasi dapat lebih mengetahui kebutuhan psikososial anak, antara lain: Anak harus dipersepsi sebagai seseorang dengan kualitas-kualitas individu yang memiliki kebutuhan, keinginan, temperamen, kepribadian dan keterampilan. Komunikasi yang diberikan kepada anak disabilitas memang sedikit berbeda tergantung dengan jenis disabilitas anak.

Saat ini juga banyak orangtua yang bekerja, maka dari itu waktu berasama anakpun dirasa kurang. Anak lebih sering bersama dengan orang lain misalnya pembantu rumah tangga dibandingkan dengan kedua orangtuanya. Orangtua juga tidak secara maksmimal mendampingi anak dengan disabilitas. Hal ini dinyatakan oleh Deputi Bidang Keluarga Sejahtera dan Pemberdayaan Keluarga BKKBN, Sudibyo Alimoeso (2013) melalui sindonews.com, bahwa

"asuhnya kepada para pembantu atau pengasuh. Hal ini banyak dilakukan orangtua yang harus bekerja."

Hal ini memang sudah banyak terjadi di wilayah perkotaan, karena biaya hidup yang cukup tinggi. Berbeda dengan masyarakat perkotaan, masyarakat di pedesaan kurang mengetahui bagaimana pengasuhan kepada anak dengan disabilitas, oleh karena itu perlu adanya edukasi kepada masyarakat khususnya orangtua yang mempunyai anak dengan disabilitas. Dengan adanya pengasuhan yang baik dari orangtua maupun keluarga besar, akan terlihat pengembangan dari dalam diri anak, karena pada dasarnya anak mempunyai potensi yang dapat dikembangkan. Memang, orangtua harus secara ekstra menjaga anak dengan disabilitas tetapi dengan ketulusan hati, orangtua tidak akan merasakan kelelahan ataupun emosi.

Setiap anak tidak terkecuali anak dengan disabilitas mempunyai hak yang sama. Menurut Komnas Perlindungan Anak (2009), empat dasar hak yang harus didapatkan oleh anak antara lain:

1. Hak hidup lebih layak

Misalnya seperti berhak atas kasih sayang orang tua, ASI eksklusif, akte kelahiran dan lain sebagainya. Setiap anak, tidak terkecuali anak dengan disabilitas berhak mendapatkan kehidupan yang layak. 
2. Hak tumbuh dan berkembang

Contoh seperti hal atas pendidikan yang layak, istirahat, makan-makanan yang bergizi, belajar, bermain, dan lain-lain. Setiap anak, tidak terkecuali anak dengan disabilitas berhak untuk tumbuh dan berkembang, antara lain mendapatkan kebutuhan dasar yaitu makanan yang bergizi, mendapatkan pendidikan, mendapatkan rekreasi, dan lain-lain.

3. Hak perlindungan

Contohnya yaitu seperti dilindungi dari kekerasan dalam rumah tangga, pelecehan seksual, tindak kriminal, pekerjaan layaknya orang dewasa, dan lain sebagainya. Setiap anak, tidak terkecuali anak dengan disabilitas mempunyai hak untuk mendapatkan perlindungan dari adanya kekerasan dan kriminalitas

4. Hak berpartisipasi

Setiap anak berhak untuk menyampaikan pendapat, punya suara dalam musyawarah keluarga, punya hak berkeluh kesah, dan memilih pendidikan sesuai minat dan bakat, dan lain-lain. Setiap anak, tidak terkecuali anak dengan disabilitas, mempunyai hak untuk memberikan pendapatnya, mempunyai tujuan dalam hidupnya.

Anak dengan disabilitas harus mempunyai pengasuhan yang baik terutama dari orangtua anak. Dengan adanya pengasuhan yang baik antara lain pemberian kasih sayang, perhatian, dan pemenuhan kebutuhan kepada anak, anak dapat berfungsi secara optimal.

Dalam hal ini, pekerja sosial mempunyai beberapa peran yaitu sebagai fasilitator dalam hal memfasilitasi orangtua dalam hal pengasuhan terhadap anak dengan disabilitas hal ini dapat dilakukan dengan konseling dan parent support group. Pekerja sosial dapat menjadi edukator dalam hal pemberian informasi terkait dengan anak dengan disabilitas dan bagaimana pengasuhan terhadap anak dengan disabilitas.

Pelayanan berbasis keluarga yang diberikan oleh pekerja sosial antara lain:

a. Pelayanan konseling keluarga

Pelayanan ini bertujuan membantu penyesuaian dan peran dalam mengahadi permasalahan

b. Pendidikan kehidupan keluarga

Keluarga yang mempunyai masalah dan tekanan diberi kemampuan untuk mengantisipasi berbagai masalah dan untuk mencegah kehancuran dalam keluarga.

\section{PENUTUP}

Pengasuhan yang baik harus diberikan kepada setiap anak tidak terkecuali anak dengan disabilitas. Pengasuhan dari orangtua bertujuan agar anak dapat memenuhi haknya. Setidaknya terdapat empat hak yang harus dimiliki oleh anak antara lain: Hak mendapatkan penghidupan yang layak, hak untuk tumbuh dan berkembang, hak untuk berpendapat, dan hak berpartisipasi. Akan tetapi masih banyak orangtua yang tidak menerima anak dengan disabilitas, orangtua menganggap anak mereka tidak dapat berbuat apa-apa, tidak sanggup, dan hanya bisa mengandalkan bantuan orang lain. Rasa malu dan kecewa pun dirasakan orangtua, karena mereka malu mempunyai anak yang tidak sempurnya, mereka malu orang lain mencemooh mereka. Selain itu orangtua biasanya kecewa dengan keadaan anak yang tidak bisa sesempurna anak lainnya. Akibatnya, hak-hak anak tidak secara menyeluruh terpenuhi karena tidak adanya pengasuhan yang baik. Dalam hal ini, perlu adanya informasi yang diberikan kepada orangtua, motivasi atau support dari lingkungan sekitar, dan pemberian pengertian mengenai anak dengan disabilitas. Dalam memberikan pengasuhan kepada anak dengan disabilitas, keluarga khususnya orangtua dapat mengimplementasikan fungsi keluarga berupa fungsi afeksi, keamanan dan penerimaan, identitas, kontrol, dan sosialisasi. Selain itu, parent support group dapat dipraktikan misalnya di sekolah khusus anak dengan disabilitas (SLB), perkumpulan penyandang disabilitas. Pekerja sosial dapat memfasilitasi konseling kepada orangtua dan memberikan edukasi mengenai pengasuhan kepada anak dengan disabilitas. 


\section{Buku:}

\section{DAFTAR PUSTAKA}

Dyah Wieka,dkk. 2005. Retardasi mental, Tingkat penerimaan. Jakarta: Fakultas Unika Atma Jaya Wibhawa Budi, dkk. 2010. Dasar-dasar pekerjaan sosial. Bandung: Widya Padjadjaran

\section{Jurnal:}

http://www.journal.unair.ac.id/filerPDF/2-13_1.pdf.। diunduh pada tanggal 14 Oktober 2014 http://repository.usu.ac.id/bitstream/123456789/33631/4/Chapter\%20I.pdf diunduh pada tanggal 14 Oktober 2014

lib.ui.ac.id/file?file=digital/125956-649..pdf $\backslash$ diunduh pada tanggal 14 Oktober 2014

\section{Rujukan Elektronik:}

www.idp-europe.org/docs/uio_upi_inclusion_book/8-Membantu_anak_dan_Keluarga.php diunduh pada tanggal 15 Oktober 2014

http://nasional.sindonews.com/read/763576/15/peran-orangtua-dibutuhkan-rawat-anakberkebutuhan-khusus diunduh pada tanggal 29 Oktober 2014 http://www.unicef.org/Indonesia/id/media_20985.html diunduh pada tanggal 2 November 2014 www.organisasi.org/1970/01/empat-4-hak-dasar-anak-Indonesia-menurut-seto-mulyadi-komnasperlindungan-anak.html 3 November 2014 